\title{
Review on measurement techniques and technologies to propose new rating scale measurement for Shariah Compliant Hotel industry in Malaysia
}

\author{
Hazlin Fardila Abdul Hasim, NorHapiza Mohd Ariffin, Mohd Zaki Zakaria \\ Faculty of Computer \& Mathematic Sciences, University Technology Mara, Malaysia
}

\begin{tabular}{l}
\hline \hline Article Info \\
\hline Article history: \\
Received Jan 26, 2019 \\
Revised May 10, 2019 \\
Accepted May 22, 2019 \\
\end{tabular}

Keywords:

Artificial intelligent model Fuzzy analytic hierarchy process

Measurement techniques

Rasch analysis

Shariah Compliance Hotel

\begin{abstract}
The tourism industry based on the Islamic approach is increasingly accepted by the tourists. This paper presents a review of measurement techniques and technologies' scale measurement for Shariah Compliant Hotel Industry in Malaysia. Since the use of the rating system in Syariah Hotel Industry in Malaysia has yet to be implemented, it is difficult for the industry to determine the status level of a hotel. Furthermore, the consumers are unable to make the right choice based on their own needs. This study aims to propose new Rating Assessment for Scale Measurement system focusing on hotel industry based on Shariah Compliant standard known as Shariah Compliant Hotel Rating Measurement Scale System (SCHRMS). Scale measurement will be used to ensure all the Shariah Compliant Certificates are certified with certain level and follow the same standard. Multiple characteristics and categories must be clarified or considered when processing rating assessment for Shariah Compliance (SC) hotel. To solve the multiple characteristics' issues, Fuzzy Analytic Hierarchy Process will be used. The process is accurate and suitable for selecting various types of information and can be used as a decision-making tool because it controls uncertain and inaccurate data. The raw data obtained from questionnaires as well as structured and unstructured interview will be analyzed using Rasch Analysis Method. Only this method is will be able to comply to the five main principles of analysis for a more meaningful and accurate conclusion of the research data obtained. Through this system that will developed, the problem related to rating measurement for SC hotel will be solved. The SC hotel rating system will be parallel to the conventional based hotel. The system is accepted for the convenience of Muslims as well as non-Muslims globally.
\end{abstract}

Copyright @ 2019 Institute of Advanced Engineering and Science. All rights reserved.

\section{Corresponding Author:}

Hazlin Fardila Abdul Hasim,

Faculty of Computer \& Mathematic Sciences,

University Technology Mara (UITM), Malaysia.

Email: hfardila@gmail.com

\section{INTRODUCTION}

In this current era, individuals are educated to make the best choice in life. The choices made for any facility, service or place normally are based on a rating that has been made through specific measurement system. This is to attain the best results according to the predefined features. Measurement is a process or activity to determine the quantity of something that is numerical. Measurements are more quantitative, and even acts as an instrument for assessment. In ensuring the balance of performance objectives, a manager plays an important and significant role in measuring and evaluating the organization's business and organizational performance [1]. In the process of assessing and scaling a case or situation, appropriate measurement measures should be addressed and focused. The main purpose of the measurement is to obtain numerical descriptions either in the form of objects, events or people in the real world through a 
measurement system [2]. In addition, measurement is a systematic process to obtain quantitative quantities of an object by using standard measuring tools. This fact is also supported by statements made by [3] where measurements have two characteristics (the use of scale number and according to rules or formulas) are the number of attributes or criteria a person has, or specific objects that refer to clear rules and formulas. Based on certain rules, measurement will involve the assignment of values to objects [4]. The rules that guide the measurement process determines the type of measurement scale that is produced and the statistics that can be used with that scale. Rating scale is a tool used to assess levels of things such as the level of cleanliness, performance, skill level, procedure, process, quality, quantity, or end product. It is evaluated at the specified level within the specified range. In other word, rating scales are similar to checklists except that the scales indicate the degree of accomplishment. Relationship between scale ratings and survey measures are often used in a unique way by different respondents. The reaction style refers to the way respondents assign a rating to items that are not relevant to the content of the item [5].

Based on a record by the Ministry of Tourism and Culture Malaysia, under the Licensing Division of the Ministry of Tourism and Culture Malaysia, a total of 2091 hotels are registered. According to the Malaysian Islamic Tourism Center, there are approximately 285 Shariah-compliant hotels in Malaysia. These include both fully shariah-compliant and partly shariah complaint. Although many hotels are built in Malaysia, however, shariah-compliant hotel or better-known Hotel Halal can still be considered less. There are mostly three- or four-star hotels in Malaysia that incorporate services and implement shariah compliant facilities for both Muslim and non-Muslim customers and issued with a halal certificate by the Department of Islamic Development Malaysia (JAKIM) specifically for the hotel's kitchen [6]. Hotel operators franchised by franchisors based in the United States of America, Singapore or United Kingdom, do not have any opportunity or chance to run the business according to Halal and Islamic compliances. Most of the four- and five-star hotels in Malaysia do not belong to local operators but are owned by foreign operators [7]. Although Malaysia is regarded as an Islamic country, however, a specific Halal Act has yet to be adopted in the halal certification for the recognition of Halal Hotel certificates. However, agencies such as JAKIM, Islamic Tourism Centre, Department of Standards Malaysia (DSM) and several agencies have collaborated to introduce the Halal Act to the hotel industry [8]. Perdana Hotel Kota Bharu is one of the luxury 5-star hotel where their operation is based on two Malaysian Halal Standards, which are MS1900:2005 for Quality Management System and MS1500:2004 for Halal Food Management (production, handling and storage). The concept of the Shariah-Compliant Manager (SCM) is implemented to control all operations involving halal standards. Each department of the hotel must have SCM's approval to carry out all activities to ensure that no non-halal activities are operated in a shariah-compliant hotel. Implementation of daily activities comprise all levels including financial management that incorporate Islamic banking system, staff management in terms of uniforms is in accordance to Syariah, procedures and activities as well as the building's architecture has Islamic features. Basic requirements such as surau, Al-Quran, prayer mats, ablution facilities, Qibla directions, Quran guidance classes and Qiamulai for employees and customers are provided and adhered.

However, the implementation of the shariah-compliant for daily operation is yet to be recognized by the authorities as any facility to measure the compliance of a hotel in implementing shariah-based laws is yet to be determined. The main purpose of this paper is to review and propose new measurement techniques in developing and validating efficiency models to measure rating scales according to the standards for the shariah compliant hotel industry in Malaysia. Reviewing previous studies in the development and validation of measurement instrument for a related field have demonstrated various examples of measurement technologies used to enhance and empower the related area. It will be guided in the process of determining the appropriate measurement system to overcome the problem of the inability of measurement in determining the level of shariah-compliant implementation. This process is expanded by obtaining information from multiple research studies to validate the use of various measurement technologies. Assessment of the diversity of this issue is to collect overall information from multiple views of measurement technology environment. To overcome the problem of scale measurement in the rating of a shariah-compliant hotel, the best technique is to use the Fuzzy Analytic Hierarchi Process (Fuzzy AHP) method. This method will be used to evaluate service quality in the related industry [9]. Through the study, it is found that AHP has many advantages in explaining the decision-making process. Among them, to illustrate a secularist that is easily understood by all parties involved in decision making [10]. The use of this method, the problems encountered can be resolved.

\section{LITERATURE RIVIEW}

\subsection{Measurement Technologies}

A measurement process is conducted to provide an option for activities done every day. Measurement is the mapping of relationships between the two main systems of quality relationship systems 
connected with the numerical relation system. The development of the systems should be based totally on the idea in the progression of philosophy and mathematics. It must also be guided by way of compliance with dimension mapping requirements.

Today, measurement systems are often used significantly to serve as the last potential of obtaining statistics from the real world, from more than one discipline and area. Measurement is broadly used as a key for obtaining e high-quality information from the industry, across disciplines [11]. Measurements can be divided into two different types, basic measurements and measurements obtained. Measurements occur in the early stages of scientific development, when some basic concepts are measured for the first time [12]. Technology intelligence (TI) is an activity that supports decision making at many levels. Various methods, concepts, and techniques have been developed and implemented for numerous purposes.

Currently, there are several software that can be used to measure raw data using statistic module such as Statistical Package for Social Software (SPSS), Analysis of Moment Structure (AMOS), RASCH Model, MITALAB, Statistical Analysis System (SAS), LISREL, EVIEWS, R-SOFTWARE and Statistical and Data (STATA). Each software has specific specialty. Suitable software selection is very important to obtain the best result of the analysis. The methods of measurement for selected areas are discussed in Table 1.

Table 1. Measurement in Related Area

\begin{tabular}{|c|c|c|c|c|}
\hline No & $\begin{array}{c}\text { MEASUREMENT } \\
\text { AREA }\end{array}$ & METHOD & FINDINGS & $\begin{array}{c}\text { AI } \\
\text { Technology } \\
\end{array}$ \\
\hline \multicolumn{5}{|c|}{ Hospitality Industry. } \\
\hline \multicolumn{5}{|c|}{$\begin{array}{l}\text { The continued improvement in service providers in various aspects of the hospitality sectors in Malaysia not only limits the process of } \\
\text { innovation performance but also the general commitment of management practice to manage service innovation. From the measurement } \\
\text { processes previously studied, there are new findings that the industry can use in upgrading various sectors of the industry. }\end{array}$} \\
\hline 1 & Tourism & - SPSS17. & The lack of understanding, knowledge, and & YES \\
\hline [13] & $\begin{array}{l}\text { Accommodations in } \\
\text { the Pilgrimage Urban } \\
\text { Areas. }\end{array}$ & $\begin{array}{l}\text { - Analysis of variance (ANOVA) } \\
\text { - Pearson's 'r' }\end{array}$ & $\begin{array}{l}\text { implementation of seven environmental performance } \\
\text { (EP) classes to investigate the EP of accommodation in } \\
\text { Mashhad City will indicate a lack of knowledge of } \\
\text { these problems. }\end{array}$ & \\
\hline $\begin{array}{c}2 \\
{[14]}\end{array}$ & $\begin{array}{l}\text { Innovation and } \\
\text { sustainable growth } \\
\text { measurement. }\end{array}$ & $\begin{array}{l}\text { - Analytic hierarchy process } \\
\text { (AHP) } \\
\text { - Super Decisions software }\end{array}$ & $\begin{array}{l}\text { States how indicators can be used to monitor innovation } \\
\text { and sustainability in the tourism industry in a relevant } \\
\text { and beneficial manner. }\end{array}$ & YES \\
\hline $\begin{array}{c}3 \\
{[15]}\end{array}$ & $\begin{array}{l}\text { Service Innovation } \\
\text { Performance- Team } \\
\text { Culture and } \\
\text { Knowledge Sharing } \\
\text { Behaviour. }\end{array}$ & $\begin{array}{l}\text { - Partial least squares (PLS) } \\
\text { - Smart PLS M3 Version } 2.0 \\
\text { software. } \\
\text { - Bootstrapping technique }\end{array}$ & $\begin{array}{l}\text { Developing a strong team culture and knowledge- } \\
\text { sharing behavior between hotel management and staff } \\
\text { will to accelerate the overall performance of service } \\
\text { innovation while providing higher experiences for } \\
\text { consumers. }\end{array}$ & YES \\
\hline \multicolumn{5}{|c|}{ Halal Industry. } \\
\hline \multicolumn{5}{|c|}{$\begin{array}{l}\text { The halal industry is increasingly becoming an important economic driver in contributing to the nation. The halal industry is expected to grow } \\
\text { in parallel to the growth of the Muslim population. To ensure the growing and improvement of this industry, several studies and research } \\
\text { have been done to measure several areas in this industry. }\end{array}$} \\
\hline 4 & Halal Status of & - SPSS version 18.0 & The presence of alcohol or ethanol in the medication & NO \\
\hline [16] & $\begin{array}{l}\text { Respiratory } \\
\text { Pharmaceutical } \\
\text { Products. }\end{array}$ & & $\begin{array}{l}\text { will be categorized as 'haram'. Products that contain } \\
\text { alcohol, but the final product in a solid state is } \\
\text { considered as halal if other sources do not contain } \\
\text { 'haram' or 'mushbooh' substances. The pharmaceutical } \\
\text { manufacturers only stated the content of the active } \\
\text { ingredients but not the excipients/inactive ingredients in } \\
\text { their medication leaflets. Because of that more than half } \\
\text { of the products could not be evaluated. }\end{array}$ & \\
\hline $\begin{array}{c}5 \\
{[17]}\end{array}$ & $\begin{array}{l}\text { Restaurant Manager } \\
\text { Expectations. }\end{array}$ & $\begin{array}{l}\text { - SPSS version } 18.0 \\
\text { - Factor Analysis and Cluster } \\
\text { Analysis }\end{array}$ & $\begin{array}{l}\text { Showed that respondents had excessive expectations } \\
\text { toward halal certification where seven important } \\
\text { elements emerged from factor analysis. }\end{array}$ & YES \\
\hline \multicolumn{5}{|c|}{$\begin{array}{l}\text { Tourism Industry. } \\
\text { Tourism is an area that is increasingly viewed by the community. Various studies have been conducted by researchers to upgrade their quality } \\
\text { from various angles. One of the important part to be measured is the environmental performant (EP). Since the late } 80 \mathrm{~s} \text {, the government, } \\
\text { private sector and the public are already interested in the environment performance. Environment exercises adopted in accommodations can } \\
\text { measure EP. These measurements focus on several key areas including recycling, waste reduction, education, environmental planning and } \\
\text { management, and the sensitivity of hotel managers as well as behavioral journeys to environmental management [18, 19]. }\end{array}$} \\
\hline $\begin{array}{c}6 \\
{[20]}\end{array}$ & $\begin{array}{l}\text { Cultural values and } \\
\text { norms of Chinese } \\
\text { mass travelers. }\end{array}$ & $\begin{array}{l}\text { - Exploratory Factor Analysis } \\
\text { (EFA) } \\
\text { - Confirmatory Factor Analysis } \\
\text { (CFA) } \\
\text { - AMOS analysis }\end{array}$ & $\begin{array}{l}\text { The cultural values and norms of Chinese mass travel } \\
\text { behavior based on the experience of travelers using the } \\
\text { budget hotel, which is a recent hotel sector in China } \\
\text { studied and explored. }\end{array}$ & YES \\
\hline
\end{tabular}




\begin{tabular}{|c|c|c|c|c|}
\hline No & $\begin{array}{c}\text { MEASUREMENT } \\
\text { AREA }\end{array}$ & METHOD & FINDINGS & $\begin{array}{c}\text { AI } \\
\text { Technology }\end{array}$ \\
\hline $\begin{array}{c}7 \\
{[21]}\end{array}$ & $\begin{array}{l}\text { Consumer perception } \\
\text { of CSR. }\end{array}$ & $\begin{array}{l}\text { - Exploratory factor analysis } \\
\text { (EFA) } \\
\text { - Principal component analysis } \\
\text { (PCA) } \\
\text { - Varimax rotation } \\
\text { - AMOS analysis } 22.0\end{array}$ & $\begin{array}{l}\text { Develop new scales to measure perceptions of corporate } \\
\text { social users' responsibility (CSR) in the tourism } \\
\text { industry. Results show the } 3 \text {-dimensional } 18 \text { item scale } \\
\text { for measuring consumer perception of CSR activities in } \\
\text { the tourism industry. }\end{array}$ & YES \\
\hline $\begin{array}{c}8 \\
{[22]}\end{array}$ & $\begin{array}{l}\text { Practitioners' } \\
\text { creativity. }\end{array}$ & $\begin{array}{l}\text { - Exploratory factor analysis } \\
\text { (EFA) } \\
\text { - Confirmatory factor analysis } \\
\text { (CFA) } \\
\text { - Kaiser-Meyer-Olkin (KMO) }\end{array}$ & $\begin{array}{l}\text { Identifying } 5 \text { critical qualities of creativity: process, } \\
\text { creativity, culture, proactive personality, and } \\
\text { satisfaction }\end{array}$ & YES \\
\hline \multicolumn{5}{|c|}{$\begin{array}{l}\text { The tourism industry based on the Islamic approach is increasingly accepted by all aspects of tourism not only of Islamic tourist but also of } \\
\text { non-Muslims. It represents a huge and high profit market in the global tourism industry. The new development in the world of Islamic } \\
\text { tourism have raised the need for industry players including hotel, restaurant, airline, and tour operators to tailor their product and service to } \\
\text { cater for the growing market segmentation's requirement. }\end{array}$} \\
\hline $\begin{array}{c}9 \\
{[1]}\end{array}$ & Predicting efficiency. & $\begin{array}{l}\text { - Multi Criteria Decision Making } \\
\text { (MCDM) } \\
\text { - Neural networks } \\
\text { - TOPSIS }\end{array}$ & $\begin{array}{l}\text { Using the TOPSIS methodology to present an } \\
\text { assessment of the competitiveness of Malaysian Islamic } \\
\text { banks. The variables related to cost structure have a } \\
\text { prominent negative impact on efficiency levels } \\
\text { identified [23]. }\end{array}$ & YES \\
\hline $\begin{array}{c}10 \\
{[24]}\end{array}$ & $\begin{array}{l}\text { Displaced } \\
\text { commercial risk in } \\
\text { Islamic Banks. }\end{array}$ & $\begin{array}{l}\text { - Value-at-risk (VaR) measure. } \\
\text { - Alpha coefficient } \alpha C A R \\
\text { - Historical non-parametric VaR, } \\
\text { - Extreme Value Theory-VaR }\end{array}$ & $\begin{array}{l}\text { Quantify the displaced commercial risk (DCR) based on } \\
\text { quantitative finance techniques. Helps to better assess } \\
\text { the needed equity to cover the DCR and an accurate } \\
\text { capital adequacy ratio for Islamic banks. }\end{array}$ & YES \\
\hline
\end{tabular}

\subsection{Artificial Intelligent (AI) Technology for measurement system}

Fuzzy logic is a rule-based system that can rely on the practical experience of an operator, particularly useful to capture experienced operator knowledge. Generally, it is a technique for reasoning similar to human reasoning or thinking. Table 2 shows several AI Technology methods that have been used in measurement process.

Table 2. Artificial Intelligent (AI) Method

\begin{tabular}{|c|c|}
\hline AI Method & Description \\
\hline $\begin{array}{l}\text { Simple Additive Weighting Method } \\
\text { (SAW) }\end{array}$ & $\begin{array}{l}\text { The basic concept of the SAW method is to find the weighted sum of the performance } \\
\text { rating on every alternative of all the attribute }\end{array}$ \\
\hline Weighted Product Model (WPM) & $\begin{array}{l}\text { WPM is one of the solutions to decide on the support systems. This method evaluates few } \\
\text { alternatives to a set of attributes, where each attribute is independent of each other. }\end{array}$ \\
\hline Fuzzy SERVQUAL & $\begin{array}{l}\text { The SERVQUAL scale used as a diagnostic technique for identifying, in various types of } \\
\text { services, the strengths and weaknesses of the company, providing the basis for continuous } \\
\text { improvement. It can also be used for various applications, including the identification of } \\
\text { trends in service quality when applied regularly with customers. }\end{array}$ \\
\hline Technique for Order Preference by & The TOPSIS method is based on the concept that the best selected alternatives not only \\
\hline Similarity to Ideal Solution (TOPSIS) & $\begin{array}{l}\text { have the shortest distance from the ideal solution but also have the longest distance from } \\
\text { the ideal solution [23]. }\end{array}$ \\
\hline Fuzzy AHP & $\begin{array}{l}\text { Fuzzy AHP, which is a fuzzy extension of AHP, is applied to solve the hierarchical fuzzy } \\
\text { decision-making problems with fuzzy scales instead of crisp numbers [23]. Fuzzy AHP } \\
\text { method will be used to evaluate service quality in the related industry [9]. }\end{array}$ \\
\hline Decision-Making Trial and Evaluation & To illustrate the structure of intricate causal relationships with matrices or digraphs, the \\
\hline Laboratory (DEMATEL) Method & $\begin{array}{l}\text { DEMATEL method is very practical to use [25]. By giving priority to the criteria based on } \\
\text { the type of relationship and the severity of their influence on each other the DEMATEL } \\
\text { method is an effective procedure for analyzing the structure and the relationship between } \\
\text { components. }\end{array}$ \\
\hline Fuzzy Outranking Method & This method compares two alternatives with loose relationships [26]. \\
\hline $\begin{array}{l}\text { Hybrid Multicriteria Decision-Making } \\
\text { (MCDM) }\end{array}$ & $\begin{array}{l}\text { MCDM is a decision-making method for setting the best alternatives of a few alternatives } \\
\text { based on certain criteria. Criteria is usually the size, rules or standards used in decision } \\
\text { making. According to [27], MCDM with AHP may present an appropriate asset which } \\
\text { presents a theory of measurement through pairwise comparisons and relies on the } \\
\text { judgments of experts to derive priority scales. }\end{array}$ \\
\hline
\end{tabular}

\section{DISCUSSION}

Performance measurement has been becoming complicated, and its focus has shifted from costreduction to growth in the current business environment. This paper adopts the pragmatic standpoint, that is, despite the complexities and ambiguity in the decision-making regarding performance measurement systems, 
performance is measured, and measurement and evaluation are widely used in contemporary organizations. Based on literature review, the best method and technology to develop system for scale measurement for Shariah Compliance hotel is identified. Literature review, in-depth interviews, and panel review will generate a list of Shariah Compliance characteristics for Islamic Hotel. The characteristics of the Shariah Compliance will be based on the standard that provided by Department Standard Malaysia (DSM). The standard is MS 1900:2014 (Shariah-based quality management systems-Requirements with guidance-First revision), MS 2446:2012 (Accommodation premise - Classification - Criteria and requirements for hotels) and MS 2610:2015 (Muslim Friendly hospitality services-Requirement). From that standard, all characteristics will be categorized based on main group. Pilot study will be conducted over current implemented Islamic or shariah compliance hotel through given set of questionnaires to obtain the information and detail experience from the organization's committee members, staff, customers and relevant authorities.

Based on the study from previous researches, the best analysis model for this study is the Rasch Analysis Model. The Rasch measurement model consists of a set of instructions, aimed at meeting the requirements for scientifically measurable for applied in social science studies [28]. According to [29] there are five (5) main principles in the Rasch measurement model necessary to be complied for meaningful and accurate conclusion of the research data obtained. The five principles are, giving a linear measure with the same interval, performing the right estimation process, finding inaccurate items (misfits) or outliers, overcoming lost data and generating replicable measurements (independent of the observed parameters). By using Rasch measurement model, the importance of calibrating the measurement instruments are also highlighted, which involves separating the misfit raw data through the analysis to ensure statistically accurate analytical results. Evaluation of the quality of the technical aspects for each of the involved item is very important in the measurement model [28]. The analysis will be able to improve the reliability of the items which could indirectly serve the purpose of calibrating the instrument to ensure a more accurate measurement in producing a meaningful research.

Upon receiving the usable questionnaires, fit statistic is used to assess the extent to which the participants of the research (mention above) and the items or characteristics from questionnaire can be collected in a same construct. Through this process, items found misfit or not matching, such as measuring constructs different than the item in the test, should be exempted or considered for review. Any question or characteristic under misfit category will be reviewed for future action. Referring to fit statistic context, some important aspects are noted covering infit, outfit, mean-square and standardized mean [30]. Through observation run, data compliance with expectations is modeled. Triangulation Methodology will also be implemented in this study. The use of a triangulation approach in a single inquiry is intended to enhance the reliability of the raw data collected, given the diversity of strategies used to collect data.

For development, the fuzzy measurement system for Shariah Compliance Rating System for Hotel in Malaysia (SCHRS) will be developed. The Fuzzy Analytic Hierarchy Process (Fuzzy AHP) method for best multi criteria decision making process will be employed. Fuzzy AHP is a more complicated procedure and requires more numerical estimations in evaluating composite compared to the traditional AHP [31]. Fuzzy AHP was carried out using AHP and then combined with Fuzzy which used to obtain weight criteria and rank the importance of sustainable development strategy criteria [32]. The choice of Fuzzy AHP as a methodology is accurate and suitable for selecting various types of information and can be used as a decision-making tool because it controls uncertain and inaccurate data.

\section{CONCLUSION}

This paper reviews and proposes new measurement techniques in developing efficiency models in measuring rating scales according to the standards for the shariah compliant hotel industry in Malaysia. Reviewing previous studies in the development and validation of measurement instrument for a related field demonstrates the various example of measurement technologies used to enhance and empower the related areas. It will be guided in the process of determining the appropriate measurement system to overcome the inability of measurement in determining the level of shariah-compliant implementation. Through the development of this SCHR system, the difficulty in determining the Shariah compliant hotel level or rating can be overcome and analyzed. This is the simplest way of choosing the accommodation by Muslim tourists and travelers and other travelers as well. This system can be used throughout the world which recognizes the shariah-compliant standards employed. The selected AI method such as Fuzzy AHP can run an efficient and precise decision-making process. With the success and effectiveness of the system to be developed will facilitate and benefit the hospitality industry based on Islamic characteristics. Thus, the Islamic based hotel rating system is on par as the rating system of conventional based hotel. 


\section{REFERENCES}

[1] P. F. Drucker, "Management: Tasks, Responsibilities, Practices," Harper Business Edition, pp. 49-58, 1993.

[2] F. Sai, "Applying Fuzzy Outranking Method to Measurement System of Multidimensional Performance," vol. 25, pp. 345-352, 2011.

[3] A. Zainul and N. Nasution, "Penilaian Hasil Belajar," Jakarta, Departmen Pendidikan Nasional, 2001.

[4] S. S. Stevens, "On the theory of scales of measurement," Science, vol. 103, pp. 677-680, 1946.

[5] L. J. Cronbach, "Response Sets and Test Validity," Educational and Psychological Measurement, vol. 6, pp. 475494, 1946.

[6] Z. Samori and N. Sabtu, "Developing Halal Standard for Malaysia Hotel Industry: An Exploratory Study," 2014.

[7] Y. Aryanty and N. A. Othman, "Awareness and Attitudes towards Hotel Operation According to Syariah Compliance in Malaysia," Prosiding Seminar Pengurusan Perhotelan \& Pelancongan Islam 2010, CITU, UiTM, pp. 268-27, 2010.

[8] R. M. Rasit, "Ciri-Ciri Hotel Patuh Syariah Terhad Malaysia: Satu Tinjauan Literatur," 2015. Available: https://www.researchgate.net/publication/281447020

[9] Lee, et al., "Afuzzy AHP and BSC approach for evaluating performance of IT department in the manufacturing industry in Taiwan," Expert Systems with Applications, vol. 34, pp. 96-107, 2008.

[10] Kusrini, "Konsep dan Aplikasi Sistem Pendukung Keputusan," Andi, Yogyakarta, 2007.

[11] G. B. Rossi and F. Crenna, "A formal theory of the measurement system," Journal of Physics: Conference Series, pp. 772, 2018

[12] F. S. Roberts, "Measurement Theory with Applications to Decisionmaking, Utility, and the Social Sciences," Encyclopedia of Mathematics and its Applications, vol. 7, 2009.

[13] A. Aminian, "Environmental Performance Measurement of Tourism Accommodations in the Pilgrimage Urban Areas: The Case of the Holy City of Mashhad, Iran," 2011.

[14] G. Gogus, et al., "Innovation and sustainable growth measurement in hotel industry: Ahierarchical decision making model," 2013.

[15] K. Hussain, et al., "Measuring Service Innovation Performance through Team Culture and Knowledge Sharing Behaviour in Hotel Services: A PLS Approach," International Research Symposium in Service Management, IRSSM-6 2015, pp. 11-15, 2015.

[16] N. A. Aziz, et al., "Assessment of the Halal Status of Respiratory Pharmaceutical Products in a Hospital," Procedia - Social and Behavioral Sciences, vol. 121, pp. 158-165, 2014.

[17] S. Z. S. Marzuki, et al., "Measurement of Restaurant Manager Expectations toward Halal Certification Using Factor and Cluster Analysis," Procedia - Social and Behavioral Sciences, vol. 121, pp. 291-303, 2014.

[18] M. A. Mayaka, "Systems approach to tourism training and education: the Kenyan case study," Tourism Management, vol. 1, pp. 298-306, 2007

[19] S. Ayuso, "Comparing voluntary policy instruments for sustainable tourism: the experience of the Spanish hotel sector," Journal of Sustainable Tourism, vol. 2, pp. 144-159, 2007.

[20] L. Ren and H. Qiu, "Developing a measurement scale for cultural values and norms of Chinese mass travellers," Journal of Hospitality and Tourism Management, 2018.

[21] M. Fatma, et al., "Measuring consumer perception of CSR in tourism industry: Scale development and validation," Journal of Hospitality and Tourism Management, vol. 27, pp. 39-48, 2016.

[22] J. S. Horng, et al., "Measuring practitioners' creativity in the Taiwanese tourism and hospitality industry," Thinking Skills and Creativity, 2015.

[23] Kutlu A. C. and Ekmekçioğlu M., "Fuzzy failure modes and effects analysis by using fuzzy TOPSIS-based fuzzy AHP," Expert Systems with Applications, vol. 39, pp. 61-67, 2012.

[24] K. Toumi, et al., "Measurement of the displaced commercial risk in Islamic Banks," The Quarterly Review of Economics and Finance, 2018.

[25] E. Fontela and A. Gabus, "The DEMATEL Observer, DEMATEL 1976 Report," Battelle Geneva Research Center, Switzerland, Geneva, 1976.

[26] F. Sai, “Applying Fuzzy Outranking Method to Measurement System of Multidimensional Performance,” 2011.

[27] M. E. Mohadab, et al., "AHP and TOPSIS applied in the field of scientific research," Indonesian Journal of Electrical Engginering and Computer Science, vol. 14, pp. 1382-1390, Jun 2019.

[28] T. G. Bond, "Validity and assessment: A Rasch measurement persepective," Metodologia de las Ciencias del Comportamiento, vol. 5, pp. 179-194, 2003.

[29] M. Mok and B. Wright, "Overview of Rasch Model Families," in Introduction to Rasch Measurement: Theory, Models and Applications, Minnesota, Jam Press, pp. 1-24, 2004.

[30] J. M. Linacre, "Patent No. Version 3.68.2," 2009.

[31] S. Perçin, "Use of fuzzy AHP for evaluating the benefits of information-sharing decisions in a supply chain," Journal of Enterprise Information Management, vol. 21, pp. 263-284, 2008.

[32] I. Santoso, et al., "Fuzzy sequential model for strategic planning of small and medium scale industries," TELKOMNIKA Telecommunication Computing Electronics and Control, vol. 17, pp. 1310-1316, Jun 2019. 


\section{BIOGRAPHIES OF AUTHORS}

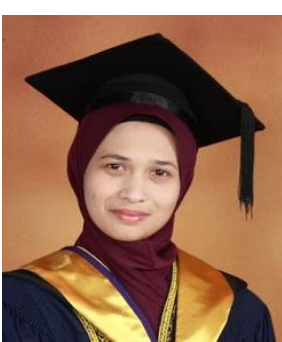

Hazlin Fardila Abdul Hasim received her B.S. (2006) in Information Technology from Universiti Tenaga Nasional (UNITEN) Malaysia, and the M.S. (2009) in Information Technology from Universiti Teknologi MARA (UITM) Malaysia. She is currently working on her Ph.D. in Information Technology at Universiti Teknologi MARA. Her research interests include Shariah Compliant Hospitality, measurement technology, Artificial Intelligent and Scale measurement. Email: hfardila@gmail.com

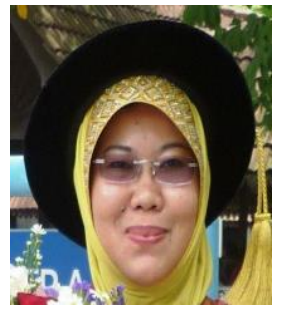

Dr. NorHapiza Mohd Ariffin received her BSc Hons in Computer Science (1994), MSc in Information Technology (IT) (2001) and Ph.d in Computer Science from Universiti Kebangsaan (UKM), Malaysia. Her research interests include Strategic Relationship Management (CRM), Strategic Information System Planning (SISP), Performance Evaluation Support System, Human Capital, Spiritual Information System, Online Distant Learning, Social Network and Service Science.

Email: hapiza@tmsk.uitmedu.my

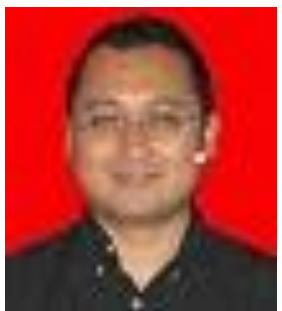

Dr. Mohd Zaki Mohd Zakaria received his BSc in Physic (1996) from University Malaya, Malaysia, He continue his study in MSc in Information Technology (2001) from Universiti Sains Malaysia (USM), Malaysia. He received his Ph.d in Electrical Engineering (2017) from Universiti Kebangsaan Malaysia (UKM). His research interest in radio frequency and identofocation (RFID), Optimization and Hybrids.

Email: zaki@tmsk.uitm.edu.my 